\title{
Den blendede undervisers roller og kompetencer
}

\author{
Inger-Marie F. Christensen, Syddansk Universitet \\ Christopher Kjær, Syddansk Universitet \\ Pernille Stenkil Hansen, Syddansk Universitet
}

\begin{abstract}
Denne artikel bidrager med viden om de roller og kompetencer, der er behov for hos undervisere ifm. tilrettelæggelse, gennemførelse og evaluering af effektiv blended learning og forslag til alternative måder at organisere disse opgaver på. Via litteraturstudier identificeres de mest centrale opmærksomhedspunkter og udfordringer for den blendede underviser. Rollegallerier og kompetence-paletter præsenteret i 6 tekster gennemgås og analyseres. Det konkluderes, at der ikke er konsensus i litteraturen om roller, kompetencer og anvendelse af begreber. Samtidig er det underbelyst, hvilke roller og kompetencer, der er nødvendige for at skabe et godt blend. Fokus er oftest, hvad det kræver at varetage online delen af blended learning. Forfatterne præsenterer deres bud på den blendede undervisers roller og kompetencer og konstaterer, at det er en særdeles kompleks opgave at varetage blended learning, og at der stilles store krav til den blendede underviser. Derfor foreslås alternative måder at organisere arbejdet på, nemlig unbundling af underviserrollen, udvikling af ressourcer og tilrettelæggelse af kompetenceudvikling.
\end{abstract}

\section{Engelsk abstract}

This article contributes knowledge on the roles and competences needed in relation to the planning, delivery and evaluation of effective blended learning and suggestions for alternative ways of organising these tasks. Through literature studies, key points of attention and challenges for the blended teacher are identified. The roles and competences presented in 6 articles are described and analysed. The conclusion is that there is no consensus in the literature on roles, competences or usage of terms. At the same time, little attention is paid to the roles and competences needed to create a good blend. Most often the focus is what it takes to handle the online part of blended learning. The authors present their model of the blended teacher's roles and competences and establish that it is a tremendously complex task to handle blended learning, and that huge demands are put on the blended teacher. Therefore, alternative ways of organising the work is suggested, namely unbundling of the teacher role, development of resources and competence development for faculty. 


\section{Indledning og baggrund}

Blended learning er allerede normal praksis på mange videregående uddannelsesinstitutioner i ind- og udland og implementeringen fortsætter i stor skala (Donnelly \& McAvinia, 2012; Kliger \& Pfeiffer, 2011; Ocak, 2011) for at høste fordele såsom økonomiske besparelser, fleksibilitet, personalisering, imødekommelse af krav om digitalisering og håndtering af et øget antal studerende.

Studier viser, at blended learning kan højne studerendes engagement og læringsudbytte (Dzuiban, Hartman \& Moskal, 2004; Sahni, 2019). Men det er ikke uden udfordringer at implementere blended learning, og det synes svært at realisere de forventede gevinster (Torrisi-Steele \& Drew, 2013), opnå tilslutning fra underviserne og understøtte effektiv læring hos de studerende. Der er en del undervisere, der ser F2F undervisning som idealet (Donnelly \& McAvinia, 2012) og frygter tab af kontrol ifm. indførelse af blended learning (Shivam \& Singh, 2015; Vaughan, 2007). Hos nogle undervisere er der modvilje mod at lære at anvende ny teknologi pga. den tid, det kræver og manglende kompensation for det ekstra tidsforbrug (Kliger \& Pfeiffer, 2011).

Blended learning opleves af nogle undervisere som en trussel mod jobsikkerhed og en tidsrøver i en travl hverdag. Nogle studerende oplever, at blended learning udgør en ekstra, uønsket arbejdsbyrde eller en reduktion i deres i forvejen sparsomme tid med underviseren (Charbonneau-Gowdy \& Cechova, 2017). Endvidere peges på udfordringer som manglende træning og digitale færdigheder hos undervisere og studerende og utilstrækkelig infrastruktur (Muhtia, Suparno \& Sumardi, 2018).

De typer af blend, der implementeres, varierer fra forløb til forløb og afhænger bl.a. af fagområde, underviserens pædagogiske viden om blended learning, tekniske færdigheder og tilgængelig support. I mange blendede forløb mangler der interaktivitet, og onlinedelen består udelukkende af tekster og videoforelæsninger, der lægger op til passiv læring (Donnelly \& McAvinia, 2012). Indføres blended learning som en top-down tilgang og med en traditionel underviserstyret pædagogik samt med en forventning om, at onlinedelen udelukkende indebærer studerendes interaktion med materialer, kan det føre til manglende engagement online hos studerende med deraf følgende lavt læringsudbytte og ringe opbakning fra underviserne (Charbonneau-Gowdy \& Cechova, 2017). Meget blended learning viderefører således traditionelle undervisningsmetoder, og onlinedelen er ofte supplerende materialer. Der er derfor behov for at sætte de studerendes læring i centrum, når der designes blended læring, og i den forbindelse at gøre onlinedelen af blended learning mere aktiv og interaktiv for at realisere læringspotentialet (Donnelly \& McAvinia, 2012; Kliger \& Pfeiffer, 2011; Salter, 2006).

Kurt og Ylldırım (2018) understreger desuden, at for at blended learning skal være effektiv, må online elementerne være en integreret del af hele kurset, spille sammen med F2F lektionerne og understøtte de studerendes opnåelse af læringsmålene. Når blended learning tilrettelægges, bør man derfor redesigne hele kurset fremfor blot at identificere dele, der kan overføres til læringsplatformen, mens resten af kurset gennemføres som hidtil (Dzuiban et al., 2004).

Desuden peges på underviserens mindset og positive holdning som en vigtig faktor, da det kræver mere tid og engagement før kursusstart at forberede blended learning og at give feedback i det virtuelle læringsmiljø, mens forløbet er i gang (Sahni, 2019). Særligt interessant er det, at studerende, der har oplevet blended learning, peger på underviserens rolle som den vigtigste komponent for deres interesse og læring, mens de ser egen rolle som aktivt lærende som næstvigtigst på en liste med i alt 9 komponenter (Kurt \& Yıldırım, 2018). Implementering af blended learning handler således ikke blot om at integrere digitale teknologier men i høj grad også om, at underviseren redefinerer sin rolle og opnår kompetencer til at udfolde denne - underviseren må "relearn how to teach" (Dzuiban et al., 2004, s. 10).

Denne artikel undersøger, hvad skiftet fra F2F undervisning til blended learning betyder for universitetsundervisere, der ofte først og fremmest er forskere, der formidler deres faglige ekspertise, 
dvs. har fokus på præsentation af det faglige stof (Salter, 2006). Når dele af et kursus flyttes online ifm. omlægning til blended learning, forsvinder samtidig en del af underviserens "hjemmebane" i form af F2F lektioner, der sløjfes, og underviseren må "spille på udebane” i form af online, asynkrone og synkrone læringsrum. Hvis onlinedelen i et blended forløb skal understøtte aktiv og effektiv læring, kræves endvidere et fokusskifte fra undervisning til de studerendes læring og et rolleskifte fra underviser til facilitator online (Muhtia et al., 2018; Sahni, 2019). Men hvad præcis er det, der kræves af den blendede underviser? Denne artikel belyser og diskuterer den blendede undervisers roller og kompetencer via litteraturstudier og argumenterer for, at der er behov for nytænkning ift. hvem der løfter de opgaver, der knytter sig til effektiv blended learning.

Artiklen er rettet mod undervisere, der skal i gang med blended learning og søger at give indsigt i, hvad det kræver af kompetencer at tilrettelægge effektiv blended learning, og hvilke roller, der skal udfyldes. Den kan også med fordel læses af uddannelsesledere, mellemledere og topledere på videregående uddannelsesinstitutioner, da den viser, at det er en kompleks opgave at implementere blended learning, og peger på, hvilke typer af support og ressourcer, der bør være tilgængelige for undervisere. Sidst men ikke mindst kan pædagogiske og e-læringskonsulenter hente inspiration i denne artikel ift. sparring med og tilrettelæggelse af kompetenceudvikling for undervisere.

\section{Artiklens opbygning}

Først gøres rede for, hvordan teksterne til litteraturstudiet er fremsøgt og udvalgt. Herefter defineres artiklens nøglebegreber. Dernæst præsenteres de roller og kompetencer, der er identificeret i den fremsøgte litteratur og disse diskuteres. Pba. diskussionen giver vi vores bud på et rollegalleri og en kompetence-pallette for den blendede underviser samt forslag til, hvordan disse roller kan løftes i praksis.

\section{Metode}

\section{Litteratursøgning}

I perioden juni og juli 2019 blev der søgt litteratur om emnet via følgende databaser og tjenester: Proquests "Education Collection", Proquests "Australian Education Index", Scopus, Ebscos "Academic Search Premier", ”Den Danske forskningsdatabase” og Google scholar. Søgestrengen (("pedagogical roles" OR "teacher competenc*" OR "teacher roles" OR "teacher skills") AND ("blended learning" OR "hybrid learning" OR "e-learning" OR "online learning") AND (HE OR "higher education")) blev anvendt samt "academic blended practice". Desuden blev der foretaget kædesøgning, hvor interessante referencer, der dukkede op i de fremsøgte tekster, blev indhentet.

Teksternes relevans blev vurderet på baggrund af titel og abstract. De, der havde universitetsundervisere og -undervisning som omdrejningspunkt samt faldt indenfor en af nedenstående kategorier blev udvalgt og danner grundlag for kortlægningen af den blendede undervisers roller og kompetencer.

* Tekster, der gør rede for og begrunder behovet for at kortlægge de roller og kompetencer, der er behov for ifm. design, gennemførelse og evaluering af blended learning.

* Tekster, der beskriver én rolle eller kompetence ifm. blended learning.

* Tekster, der beskriver et rollegalleri eller en kompetence-palette ifm. blended learning.

Der er foretaget grundige studier af online underviserens roller og kompetencer, f.eks. Abdous (2011), Baran, Correia og Thompson (2011) og Carril, Sanmamed og Sellés (2013). Denne artikel er inspireret 
af disse studier, der dog ikke behandles nærmere, da vores fokus er afgrænset til en blended learning kontekst.

Teksterne, der primært er engelsksprogede, enkelte er dansksprogede, dækker bl.a. britiske, chilenske, irlandske, new zealandske, nordamerikanske, polske, saudiarabiske, skandinaviske, spanske og tyrkiske kontekster og giver således et nuanceret billede af, hvordan roller og kompetencer anskues. Teksterne behandler forskellige fagområder og niveauer af videregående uddannelse og er primært fagfællebedømte artikler og konferencebidrag. Det påstås ikke, at litteratursøgningen har resulteret i en fuldstændig dækning af emnet. Kun tekster, der refereres til i artiklen, er medtaget i litteraturlisten.

\title{
Definition af begreber
}

\section{Hvad forstår vi ved blended learning?}

Der er mange forskellige forståelser i spil, når talen falder på blended learning, og det er ofte uklart præcis, hvad der menes (Torrisi-Steele \& Drew, 2013), derfor redegør vi i det følgende for vores anvendelse af begrebet.

\begin{abstract}
Vi ser blended learning som faciliterede, aktive, interaktive og integrerede forløb, der via et hensigtsmæssigt mix af online og F2F læringsaktiviteter understøtter den studerendes arbejde med og opnåelse af de opstillede læringsmål.
\end{abstract}

Som sådan opnås blended learning ikke ved blot at føje en online aktivitet eller en digital teknologi til et F2F forløb (Vaughan, 2007). Der kræves en tilgang, hvor man med læringsmål og eksamensform som udgangspunkt, formulerer online og F2F læringsaktiviteter og mixer disse i et integreret forløb. Redesign, design af nye aktiviteter og genovervejelse af eksamensformer, er nødvendigt for at opnå effektiv blended learning. Garrison og Vaughan (2008) understreger designaspektet i deres definition af blended learning: "a design approach whereby both face-to-face and online learning are made better by the presence of the other", her citeret fra Muhtia et al. (2018, s. 172). Garrison \& Kanuka peger på integrationsaspektet i deres definition fra 2004 "blended learning is the thoughtful integration of classroom face-to-face learning experiences with online learning experiences" (D. R. Garrison \& Kanuka, 2004, s. 96). Der er således en optagethed af at tydeliggøre, at blended learning ikke er en tilfældig blanding af F2F og online læringsaktiviteter men er forløb, hvor man med omhu har udvalgt og kombineret læringsaktiviteter og teknologier for at give de studerende optimale betingelser for læring.

Sahni peger desuden på tilstedeværelse både F2F og online som en betingelse for blended learning: "It requires the physical presence of the instructor and students in the classroom and virtual presence on the chosen eLearning platform, where students have some control over time, place or pace" (Sahni, 2019, s. 2). Blended learning ses således som faciliterede, aktive og interaktive forløb på tværs af det fysiske og det virtuelle læringsmiljø. Der er ikke blot tale om at gøre online ressourcer tilgængelige for de studerende. Hertil kommer en vis grad af fleksibilitet for både underviser og studerende, da nogle F2F timer (måske) omdannes til asynkrone, online aktiviteter. Reduktion af F2F tid er et vigtigt element i nogle forståelser af blended learning, som f.eks. hos Dzuiban et al. (2004), der ligeledes understreger designaspektet og fremhæver aktiv læring, som en vigtig komponent:

\footnotetext{
"the term "blended learning" refers to courses that combine face-to-face classroom instruction with online learning and reduced classroom contact hours [...] blended learning should be viewed as a pedagogical approach that combines the effectiveness and socialization opportunities of the classroom with the technologically enhanced active learning possibilities of the online environment [...] a fundamental redesign of the instructional model [...]."

(Dzuiban et al., 2004, s. 2-3)
} 
Dzuiban et al. lister desuden 3 karakteristika indeholdt i deres forståelse af blended learning, nemlig

* et skifte fra underviser til studenter-centreret undervisning, hvor de studerende er aktive og interaktive lærende både F2F og online.

* øget interaktion mellem studerende-underviser, studerende-studerende, studerendeindhold og studerende-eksterne ressourcer.

* integrerede formative og summative evalueringsmekanismer for studerende og underviser.

Studerende som aktive og interaktive lærende samt den øgede interaktion er netop centrale elementer i vores forståelse af blended learning. Vi ser dog ikke erstatning af F2F tid med online aktiviteter, som en betingelse. Beslutningen om at erstatte F2F tid skal holdes op imod det i forvejen lave antal F2F timer på nogle videregående uddannelser og forventningen om, at den studerende bruger en del tid på selvstudier mellem de skemalagte timer. Her kan onlinedelen af et blended forløb i stedet designes som stilladsering af de studerendes aktive og interaktive forberedelse og fordybelse. Dette kan samtidig medvirke til øget studieintensitet, således at F2F timerne kan starte på et højere niveau.

\section{Roller og kompetencer}

I dette afsnit vil vi gøre rede for vores forståelse af begreberne roller og kompetencer, da det ofte er uklart, hvordan begrebet "underviserrolle" defineres (Huang, 2019), og da der ikke er enighed om terminologien (Baran et al., 2011; Carril et al., 2013).

I betegnelsen underviserrolle ligger et sæt af forventninger til en bestemt adfærd, som underviseren skal kunne udvise og specifikke funktioner underviseren skal kunne udføre (Huang, 2019; Mathiasen, 2004). Indbefattet i rollebegrebet er også relationer og kommunikation med andre samt overbevisninger og holdninger. I sit studie definerer Huang begrebet underviserrolle, som "all the teaching-related activities and behaviors that teachers do or are expected to do either before class, in class or after class across different instructional contexts" (Huang, 2019, s. 191). Vi lægger os op ad denne definition dog med den modifikation, at vi har taget "teaching-related" ud af definitionen, da vi netop stiller spørgsmålstegn ved, om alle de roller, der skal i spil i blended learning, virkelig er underviserroller eller om der er basis for nytænkning ift. hvem, der bestrider hvilke roller.

Det kræver viden, færdigheder og kompetencer at bestride en given rolle. Vi har her valgt at bruge begreberne fra Kvalifikationsrammen for Livslang Læring, da vores felt er kompetenceudvikling af undervisere og vi ønsker at synliggøre, hvad det kræver af efteruddannelse at kunne mestre jobbet som blended underviser. Vi trækker herved på den uddannelsestænkning som vægter udarbejdelse af læringsmål knyttet til viden, færdigheder og kompetencer og som retter et særligt fokus på, hvad den lærende skal kunne efter endt uddannelse frem for hvad de har været igennem af pensum (Ulriksen, 2014). Vores ærinde er at bane vejen for professionalisering af rollen som blended underviser.

Ifølge kvalifikationsrammen indeholder vidensbegrebet både teoretisk og praktisk viden om et emne samt forståelse. Ved færdigheder forstås kognitive, praktiske, kreative såvel som kommunikerende færdigheder, mens kompetencer handler om at bringe viden og færdigheder i spil i specifikke kontekster (Uddannelses- og Forskningsministeriet, 2013). Denne artikel sætter især kompetencer i centrum, dvs. hvordan den blendede underviser i en konkret praksis realiserer viden og færdigheder for at stilladsere studerendes læring både online og F2F.

I de fremsøgte engelsksprogede tekster anvendes forskellige begreber, f.eks. skills, abilities og capabilities, der dækker et spektrum fra evne over færdigheder til kompetencer. Der vil i hvert tilfælde blive foretaget en vurdering af, hvilken oversættelse, der er relevant. 


\section{Den blendede undervisers roller og kompetencer}

I dette afsnit vil vi undersøge, hvilke roller og kompetencer, der peges på i litteraturen om blended learning. Størstedelen af de fremsøgte artikler har fokus på én enkelt kompetence eller rolle, der ses som central for underviseren ift. skiftet til blended learning. Nedenfor præsenteres disse opmærksomhedspunkter.

\section{Centrale roller og kompetencer}

\section{Designer af læringsoplevelser og e-læringskonsulent}

Torrisi-Steele og Drew (2013) påpeger, at det er ekstremt krævende at designe blended learning. Underviserne skal vide, hvilke digitale værktøjer, der er tilgængelige, kende de pædagogiske fordele og ulemper ved disse og kunne gennemskue, hvordan værktøjerne bedst integreres i de planlagte læreprocesser, dvs. at blended learning i stigende grad fordrer, at underviseren skal være læringsdesigner. Denne pointe understøttes af Yu Lei (2010), der forklarer, at underviseren har ændret sig fra at være forfatter af læringsindhold til at være designer og én, der overvåger, understøtter og guider studerendes læreprocesser, og af Saalman (2011), der fremhæver, at underviserne må justere deres traditionelle rolle og påtage sig rollen som designer af læringsoplevelser og -miljøer.

Bel og Mallet (2006) undersøger underviserens rolle ift. at understøtte studerendes aktive læring og bedrive konstruktionistisk undervisning ifm. blended learning på et kandidatkursus. Bel og Mallet peger på, at underviseren må besidde specifikke kritiske færdigheder i at identificere, evaluere og vælge mellem de ressourcer (digitale såvel som ikke digitale), der er tilgængelige til understøttelse af studerendes læring, når et forløb designes. Der er behov for undervisningspraksisser, der fuldt ud integrerer undervisningsmetoder og digital teknologi og ikke blot "blender" disse, hvis de studerendes oplevelse af relevans og læringsudbytte skal sikres. Ocak (2011) understreger betydningen af effektiv integration af teknologien og peger desuden på udfordringerne forbundet hermed:

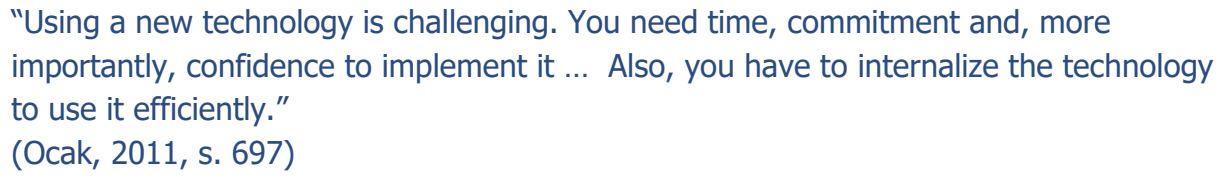

Dvs. at underviseren også skal kunne udfylde rollen som e-læringskonsulent, der har indgående kendskab til e-læringsplatform og værktøjer og kan vurdere hvilket værktøj, der bedst understøtter en given læreproces.

\section{Facilitatorrollen og underviserens online tilstedeværelse}

Facilitatorrollen er én af de roller, der oftest bliver nævnt og behandlet, herunder den viden, de færdigheder og kompetencer, som underviseren skal besidde for at kunne engagere de studerende aktivt i onlinedelen af et blended forløb. Underviserens evne til at udfylde facilitatorrollen har vist sig at være afgørende for at realisere læringspotentialet (Abdous, 2011; Donnelly \& McAvinia, 2012; Huang, 2019; Kliger \& Pfeiffer, 2011; Sahni, 2019; Sajdak \& Koscielniak, 2014; Salmon, 2011; Salter, 2006).

Jeffrey, Milne, Suddaby og Higgins (2014) har bl.a. gennem et omfattende litteraturstudie identificeret 3 kategorier af strategier til at engagere de studerende i blended learning. Første kategori handler dels om at vække de studerendes nysgerrighed og gøre indhold vedkommende, og dels om at skabe et inkluderende læringsmiljø, hvor underviseren får de studerende til at føle, at de er en del af fællesskabet. Anden kategori dækker over metoder til at opretholde de studerendes engagement undervejs i forløbet, og den tredje kategori handler om at genskabe/vække frafaldstruede studerendes engagement ved at 
spotte dem tidligt og tage personlig kontakt. Jeffrey et al.s strategier kan anvendes i F2F delen, men er særlig vigtige i onlinedelen, da undervisere ofte undervurderer deres rolle og betydningen af deres online tilstedeværelse i blended learning.

Flere studier fremhæver netop underviserens online tilstedeværelse som afgørende for de studerendes deltagelse, tilfredshed og læringsudbytte i blended og online undervisning (Al Ghamdi, Samarji \& Watt, 2016; Anderson, 2017; Carril et al., 2013; Ocak, 2011; Okaz, 2015; Sajdak \& Koscielniak, 2014; Salmon, 2011). Studerende kan føle sig isolerede og fremmedgjorte (Okaz, 2015) i online delen af et blended forløb, hvor der ikke er kommunikation mellem underviser og studerende og mellem medstuderende. Undervisere beretter desuden om udfordringer ift. at få studerende til at deltage i asynkron kommunikation online (Ocak, 2011). Derfor er der en optagethed af at undersøge, på hvilke måder ikke blot underviseren, men også de studerende, kan være tilstede og synlige online.

Garrison, Anderson og Archer's community of inquiry (COI) model, der bygger på en socialkonstruktivistisk problem- og undersøgelsesbaseret tilgang til undervisning og læring, har vist sig at være en brugbar model til at forstå og undersøge underviseres såvel som studerendes online tilstedeværelse i blended learning (Anderson, 2017). Modellen opererer med 3 former for tilstedeværelse - teaching, social og cognitive presence - der i et samspil er afgørende for opnåelsen af et ideelt online læringsmiljø. Teaching presence dækker over kursusdesign, facilitering og instruktioner, der har som formål at fremme sociale og kognitive processer, der understøtter de studerendes læring. Social presence er den studerendes evne til via et kommunikativt medie at projicere sig selv socialt og følelsesmæssigt og etablere en personlig online repræsentation af sig selv (Gurley, 2018). Cognitiv presence omhandler i hvilken grad de studerende er i stand til at konstruere og skabe mening gennem refleksion i et kristisk baseret COI (Anderson, Liam, Garrison \& Archer, 2001).

Underviserens rolle og adfærd som facilitator ses derfor i COI-modellen som kritisk for skabelse af aktiv læring og opretholdelse af de studerendes motiviation og engagement. Facilitatorrollen indebærer et ansvar for at etablere og opretholde dialog, opmuntre og anerkende de studerendes bidrag, skabe et tillidsvækkende læringsmiljø og sikre kvaliteten af processen (Anderson et al., 2001). Gurleys (2018) studie af teaching presence i blendede og online læringsmiljøer viser en signifikant forskel i holdninger og kompetencer til det at skabe teaching presence via facilitering hos undervisere, der har gennemført formel kompetenceudvikling.

Underviserens online tilstedeværelse indebærer også opbygning og modellering af social presence (Anderson et al., 2001). I et studie af social presence i en blended learning kontekst peger Whiteside (2015) på vigtigheden af, at underviseren, gennem sit engagement i læreprocessen, initierer og faciliterer aktiviteter, der understøtter etablering og vedligeholdelse af sociale relationer. Flere andre studier peger ligeledes på, at underviserens sociale rolle har stor betydning for de studerendes læring i blendede kontekster, men at der er behov for ydereligere forskning inden for området (Anderson, 2017; Gerbic, 2011; Huang, 2019; Keller, Wass, Zetterlind, Ghassemali \& Seifeddine, 2017; Kliger \& Pfeiffer, 2011; Ocak, 2011).

\section{Rollegallerier og kompetence-paletter}

Kun 6 ud af de fremsøgte artikler præsenterer et rollegalleri eller en kompetence-palette for undervisere, der skal tilrettelægge blended learning. Nedenfor gøres kort rede for fokus i disse tekster og i bilag 1 , tabel 1 - 6 vises roller og kompetencer. De 6 tekster repræsenterer meget forskellige tilgange og bidrager på mere eller mindre kvalificeret vis til afklaring af, hvad det kræver af underviseren at varetage den type blended learning, som vores definition på side 4 repræsenterer. Endvidere diskuteres brugbarheden af de forskellige tilgange, og de roller og kompetencer, der synes relevante ift. vores forståelse af blended learning, udpeges. 


\section{Roller og kompetencer i relation til konstruktivistisk funderet blended learning}

Sajdak og Koscielniak (2014) undersøgte, hvilke kompetencer en universitetsunderviser må besidde for at aktivere og styrke studerendes motivation i konstruktivistisk funderet blended learning og lagde således den pædagogiske tilgang til grund for undersøgelsen. Der blev udviklet en model, der beskriver funktioner, kompetencer og færdigheder fordelt på 3 roller: instructional designer: bl.a. at kunne designe læreprocesser med teknologi, facilitator 1: at kunne organisere studerendes læringsmiljø og facilitator 2: at kunne støtte og styrke studerendes motivation. I bilag 1, tabel 1 ses en sammenfatning af modellen.

Underviseren i konstruktivistisk funderet blended learning skal kunne designe fleksible forløb med mulighed for løbende tilpasning ud fra den aktuelle gruppe af studerende og deres udviklingsbehov. Andre fokuspunkter er inddragelse af studerende samt monitorering af og feedback på læring. Vi ser her et godt bud på, hvordan blended learning forankres i et konkret læringssyn med de studerendes aktive og interaktive læring som omdrejningspunkt, og hvordan dette bidrager med en ramme for identifikation af læringsmål, design af konkrete aktiviteter og facilitering af disse. Det er dog ikke tydeligt, hvordan faciliteringen kan foregå og forfatterne forholder sig ikke til, hvordan der skabes et integreret blend på tværs af F2F og det virtuelle læringsmiljø. Det konstateres blot, at der er behov for viden om muligheder og begrænsninger i relation til IKT i blended learning samt færdigheder i avanceret anvendelse.

\section{Roller og funktioner i relation til blendede engelskkurser}

Pba. af et litteraturreview af underviserroller i blended learning og observationer af blendede engelskkurser på et kinesisk universitet, peger Jia (2017) på et skifte i underviserens roller. I blended learning skal underviseren være designer af undervisningsindhold, organisator af undervisningsaktiviteter samt fokusere på integration af undervisningsmateriale og evaluering af undervisningsaktiviteter. Indholdet i disse roller og funktioner er præsenteret i bilag 1, tabel 2.

Jia har i lighed med Sajdak \& Koscielniak fokus på målene, den løbende tilpasning, de studerendes læringsforudsætninger og -niveau samt monitorering af og formativ feedback på læring. Der er desuden visse ligheder mellem Jias rolle organisator af undervisningsaktiviteter, der bl.a. har som funktion at kunne designe en positiv læringsatmosfære og motivere via design af varierende opgaver og Sajdak \& Koscielniaks facilitator 1 . Vi ser et stort potentiale i denne rolle og tilhørende kompetencer, idet intentionerne om faciliterede, aktive og interaktive forløb på denne måde italesættes og forberedes allerede i designfasen. Her skabes et solidt fundament, der understøtter realisering i praksis.

Endvidere er der hos Jia fokus på at skabe integrerede forløb, idet underviseren skal kunne designe sammenhængende online og offline opgaver og aktiviteter. IKT-kompetencer er dog begrænset til funktionen at integrere undervisningsmateriale/-ressourcer, der kræver opdateret viden samt kompetencer til at kunne udvælge, producere og tilpasse materiale og ressourcer.

\section{Fokus på IKT-kompetencer og synliggørelse af muligheder ift. platform og værktøjer}

Roszak, Kołodziejczak, Kowalewski og Ren-Kurc (2014) har særligt fokus på de IKT-kompetencer, der er nødvendige og hvilke konkrete værktøjer, der kan anvendes, når man skal undervise på et blended forløb på universitetsniveau. De polske forskere angiver at have særlig opmærksomhed på kompetencer og værktøjer i relation til skabelse af læringsfælleskaber, hensigtsmæssig udvælgelse af "student activity tools", der motiverer studerende til at arbejde systematisk, problemfri kommunikation mellem studerende og underviser og mellem studerende ifm. gruppearbejde samt hensigtsmæssig organisering 
af underviserens arbejde på e-læringsplatformen. Der tages udgangspunkt i kendte og traditionelle undervisningsformater, såsom forelæsningen, øvelsestimer, laboratoriearbejde osv. I bilag 1, tabel 3 sammenfattes Roszak et al.s bud på, hvad det kræver at forberede og gennemføre blended learning samt evaluere studerendes læring.

Artiklen har karakter af en how to manual for undervisere med best practice eksempler. En vigtig opgave for underviseren er at beslutte, hvilket stof, der skal formidles lokalt (F2F) og på distancen (online), og hvordan stoffet skal organiseres. Behovet for redesign eller designkompetencer italesættes ikke af Roszak et al., der synes at forstå blended learning ud fra en traditionel pensumtankegang. Hvad elæringsplatformen og dens værktøjer muliggør er omdrejningspunktet, snarere end hvilke læreprocesser, der vil understøtte de studerendes arbejde hen mod læringsmålene. Vi mangler derfor i høj grad det integrerede aspekt i denne fremgangsmåde samt fokus på læringsmål, læreprocesser og det at skabe et hensigtsmæssigt mix af F2F og online læringsaktiviteter. Roszak et al.s formål synes at være at synliggøre muligheder for online formidling af materialer, gruppe/projektarbejde, diskussion, kommunikation, opgaveaflevering og tests, men det bliver fragmenterede muligheder og kompetencer uden den røde tråd et mere bevidst læringsteoretisk grundlag kan tilbyde, som vi ser det hos Sajdak og Koscielniak.

\section{Et blended learning framework}

Mirriahi, Alonzo og Fox (2015) introducerer et vurderingsskema (et blended learning framework) med eksplicitte kriterier og standarder, der kan anvendes som rettesnor for kursusdesign, akademisk praksis og kompetenceudviklingsforløb for undervisere og som undervisere kan anvende som værktøj til selvevaluering, hvor stærke sider og udviklingsområder identificeres. Bevæggrunden for at introducere et vurderingsskema er, at eksplicitte kriterier og standarder kan medvirke til mere effektive lærings- og undervisningsaktiviteter, da kriterierne kan anvendes til at benchmarke akademisk praksis.

Vurderingsskemaet er udviklet med udgangspunkt i følgende definition af blended learning "a process of integrating the most appropriate learning and teaching strategies, technology and/or media to provide meaningful, flexible learning experiences to achieve learning outcomes" (Mirriahi et al., 2015, s. 3). Kriterier og standarder er organiseret omkring learning design modellen RASE (Resources, Activities, Support og Evaluation), der præsenteres i Churchill, King, Webster og Fox (2013). RASE understøtter "a student-centred, technology-rich environment suitable for BL" (Mirriahi et al., 2015, s. 4). Vurderingsskemaet har 3 faste niveauer (A - C) og yderligere et fakultetsspecifikt niveau, der kan tilpasses fagområde/kontekst. Niveau A kræver, at underviseren integrerer teknologi og tilbyder online undervisnings- og læringsaktiviteter. Her vil der være tale om mere underviserstyret anvendelse. Niveau B kræver, at underviseren anvender teknologi til at tilbyde fleksible læringsmuligheder, der er konstruktive, autentiske og kollaborative, mens niveau C bevæger sig mod en højere grad af kollaboration mellem studerende. På niveau C anvendes teknologien desuden til at skabe en højere grad af studenterdeltagelse, hvor studerende selv udvikler ressourcer og lærer med og ikke kun gennem teknologien. I bilag 1, tabel 4 præsenteres de standarder, der hører til hver af de fire komponenter i RASE modellen.

Underviserroller behandles ikke i Mirriahi et al., men vurderingsskemaet beskriver den adfærd og viden samt de færdigheder og kompetencer, der kræves af underviseren for at opnå blended learning, der er aktiv, interaktiv og integreret. Ligeledes beskrives, hvordan der skabes et hensigtsmæssigt mix af online og F2F læringsaktiviteter, som vi så hos Jia. Disse skal støtte hinanden, ikke overlappe eller gentage. Der er fokus på at have viden om forskellige teknologier og disses affordances ift. konkrete læringsmål samt at anvende teknologien til understøttelse af studerendes læring og imødekommelse af særlige behov og præferencer, som vi også ser det hos Sajdak og Koscielniak, hvor dette er indeholdt i rollen instructional designer. Samtidig skal undervisere kunne understøtte studerendes anvendelse af teknologi og træne dem i rollen som blendede lærende. Facilitator-kompetencer nævnes ikke eksplicit, men underviseren skal sikre, at studerende får løbende feedback, får mulighed for at øve sig, sætte mål 
for, følge og vurdere egen læring. Det er dog ikke tydeligt, hvornår i processen med design, gennemførelse og evaluering af blended learning, der er behov for den listede viden, de beskrevne færdigheder og kompetencer.

Mirriahi et al. (2015) er en kilde til inspiration qua vurderingsskemaets 3 niveauer, der beskriver, hvordan blended learning designs kan udvikle sig, gøres fleksible og bane vejen for øget autonomi for studerende. Vurderingsskemaet peger på en bevægelse fra underviserinitierede og -styrede aktiviteter hen mod øget studenterdeltagelse ved produktion af læringsressourcer, øget interaktion online mellem studerende, undervisere og eksterne samt valgmuligheder ift. demonstration af det lærte. Mirriahi et al.s vurderingsskema viser således, hvor underviseren, der første gang skal designe og gennemføre blended learning, kan starte og synliggør udviklingspotentialet over tid. Denne dimension savnes i de øvrige, udvalgte tekster.

\section{Kognitive, affektiv og ledelsesmæssige roller}

Huang (2019) har undersøgt og sammenlignet 152 førsteårsstuderendes oplevelse af underviseres kognitive, affektive og ledelsesmæssige roller på et blended engelskkursus i Kina. Undersøgelsen bygger på et studie af Coppola, Hiltz og Rotter (2002), der viser, at disse tre roller er fundamentale ved både F2F og online læring, men kræver særlig opmærksomhed ved online læring. Studiet er baseret på spørgeskemamodellen STRI (Scale of Teacher Role Inventory) - som Huang har udviklet til undersøgelse af underviserroller i F2F, online og blendede kontekster. I bilag 1, tabel 5 listes den adfærd, som Huang har knyttet til de tre underviserroller i sin STRI-model. Statistiske analyser af de studerendes oplevelse af underviserroller i både F2F og online læring viser, at de studerende anser den ledelsesmæssige rolle for den vigtigste, hvilket også bakkes op af Kurt \& Yildrims (2018) studie.

Det særlig interessante i Huangs fremstilling er opdelingen i den kognitive, affektive og ledelsesmæssige rolle, der kan sammenlignes med COI-modellens 3 former for tilstedeværelse (hhv. cognitive, social og teaching presence). Huangs tilgang synes dog at resultere i en palette af løsrevne forventninger på et detailniveau, der gør det svært at se en rød tråd eller den sammenhæng mellem rollerne, som COImodellen lægger op til. En reel designproces, hvor der, med udgangspunkt i de aktuelle læringsmål, arbejdes på at skabe et hensigtsmæssigt blend af online og F2F læringsaktiviteter, synes ikke at være tilstede, ligesom IKT-kompetencer heller ikke nævnes.

Under den kognitive og affektive rolle beskrives, hvordan underviseren kan understøtte studerendes læring. I den affektive rolle genfinder vi desuden i nogen grad den sociale dimension, mens tilpasning af aktiviteter til de studerendes behov er indeholdt i den ledelsesmæssige rolle. Begge dele er hos Sajdak og Koscielniak indeholdt i rollen facilitator 1. Den ledelsesmæssige rolle har endvidere fokus på at organisere og sætte rammer og regler for studerendes læring og engagement, og underviseren er i fokus som den, der styrer og initierer, hvilket også signaleres via etiketten den ledelsesmæssige rolle. Dermed synes denne rolle at falde i tråd med gennemførelse af blended learning på niveau A, som beskrevet i Mirriahi et al.s vurderingsskema men vil komme til kort, når der skal gennemføres blended learning svarende til niveau B eller C med øget studenterdeltagelse og autonomi. Disse to niveauer spiller derimod samen med Sajdak og Koscielniaks facilitator 1 og 2 roller, hvor det at skabe, vedligeholde og moderere, frem for at lede, læringsfællesskaber er i centrum.

Huang har undersøgt førsteårsstuderendes oplevelse og det er formodentligt netop disses behov for tydelig stilladsering og forventningsafstemning, der afspejles i beskrivelsen af adfærd for de 3 roller. Der kan således hentes inspiration i Huang (2019) ifm. blended learning for nye universitetsstuderende, men det synes vanskeligt at omsætte undersøgelsens resultater til kompetenceudvikling af undervisere. 


\section{Facilitator af studerendes signifikante læring}

På baggrund af litteraturstudier, en spørgeskemaundersøgelse, individuelle interviews og fokusgruppeinterviews med undervisere på en række spanske universiteter konkluderer Imbernón, Silva og Guzmán (2011), at der er behov for følgende specifikke kompetencer, når man skal varetage blended learning eller e-læring: viden om og brug af IKT værktøjer, viden om og anvendelse af planlægnings- og designteknikker i relation til virtuelle miljøer samt viden om og anvendelse af undervisningsmetoder til e-læring og b-læring (blended learning). Disse kompetencer splittes op i professionelle opgaver eller "micro-skills", som vist i bilag 1, tabel 6. Der er fokus på, hvordan kompetenceudvikling af undervisere kan designes, og hvad denne skal indeholde for at klæde underviserne bedst muligt på til at varetage den overordnede rolle som facilitator af studerendes signifikante læring, dvs. at studerendes behov bør være omdrejningspunktet. Særlige opmærksomhedspunkter er at øge underviseres viden om, hvornår det er hensigtsmæssigt at anvende virtuelle værktøjer og ressourcer, og hvornår det ikke er og at hjælpe undervisere med at udvikle kompetencer til løbende evaluering af og refleksion over professionel praksis mhp. kontinuerlig forbedring. Hertil kommer, at undervisere skal klædes på til at støtte studerende $\mathrm{i}$ at anvende virtuelle værktøjer og IT-ressourcer på måder, der gør, at de opnår viden og udvikler nye færdigheder og kompetencer ikke blot indenfor fagområdet men også ift. kommunikation og samarbejde.

Imbernón et al. har således, på linje med Jia og Mirriahi et al. fokus på, at underviseren har kompetencer til at skabe hensigtsmæssige blends af F2 F og online aktiviteter og kan anvende de bedste metoder til at opnå kursets mål. Endvidere er det vigtigt, at underviseren ikke blot forelæser online, men kan skabe aktive og interaktive forløb ved at fremme og koordinere kommunikation og samarbejde online samt skabe øget deltagelse ved at dele moderatorrollen med studerende. Facilitatorrollen italesættes dog ikke eksplicit, som hos Sajdak og Koscielniak, men det nævnes, at underviseren skal mestre både synkrone og asynkrone værktøjer til kommunikation med studerende.

Vi ser lighedspunkter mellem Imbernón et al. og Mirriahi et al. idet begge forfatter-teams er optaget af videreudvikling af blended learning praksis samt kontinuerlig kompetenceudvikling af undervisere. De peger på, at blended learning og rollen som blended underviser ikke er noget, der én gang for alle kan mestres, men derimod bør være genstand for løbende evaluering og forbedring/udvikling. Forfatterne bidrager således med et inspirerende dynamisk perspektiv, mens de øvrige tekster illustrerer mere statiske nedslag.

Gennemgangen af rollegallerier og kompetence-paletter ovenfor illustrerer de mange forskellige tilgange til og formål med kortlægning af den blendede undervisers roller og kompetencer. De udvalgte tekster giver fra hver sit perspektiv et vigtigt bidrag til en mere helhedsorienteret forståelse af et komplekst felt. I arbejdet med opstilling af vores eget rollegalleri og kompetence-palette har vi forsøgt at afspejle denne helhedsorienterede forståelse og særligt lagt vægt på, at den blendede underviser, med udgangspunkt i læringsmålene for det aktuelle forløb, skal kunne skabe og facilitere integrerede forløb med et hensigtsmæssigt mix af online og F2F aktiviteter. Det ligger os på sinde at være tæt på underviserens praksis og konkrete opgaver, og at rollegalleri og kompetence-palette kan omsættes til konkrete kompetenceudviklings-initiativer samt ressourcer, der kan understøtte underviseren, der skal varetage blended learning. I næste afsnit præsenterer vi vores bud på et rollegalleri og en kompetencepalette.

\section{Den blendede undervisers roller og kompetencer}

Gurley konkluderer på baggrund af et mixed method studie, at "educators that complete formal training programs, such as certification courses, are more confident in their abilities to facilitate student learning in blended and online courses" (Gurley, 2018, s. 216) og understreger vigtigheden af, at undervisere bliver klædt særligt på til at undervise i blended og online læringsmiljøer. Det kræver grundig og effektiv 
kompetenceudvikling, da undervisere også har behov for at arbejde med deres mindset og f.eks. opleve at være studerende på et blended forløb. Identifikation og systematisering af underviserroller og kompetencer er et vigtigt skridt ift. tilrettelæggelse af denne kompetenceudvikling (Abdous, 2011; Baran et al., 2011; Carril et al., 2013). I de tilgange til beskrivelse af underviserroller og kompetencer, vi har præsenteret ovenfor, kan det dog være svært at gennemskue præcis, hvornår i et blended forløb, en given rolle eller kompetence skal i spil. Vores bud på et rollegalleri og en kompetence-palette følger derfor processen fra tilrettelæggelse over gennemførelse til evaluering af blended learning og er inspireret af Abdous, der præsenterer "a processoriented framework structured around three sequential non-linear phases: (1) before: preparing, planning, and designing; (2) during: facilitating, interacting, and providing/gathering feedback; and (3) after: reflecting and considering lessons learned" (Abdous, 2011, s. 60). Denne procesorienterede tilgang vil være genkendelig for undervisere og kunne relateres til deres praksis.

Listen af roller og kompetencer er formuleret som læringsmål for at muliggøre omsætning til konkrete kompetenceudviklingsaktiviteter, der skal klæde undervisere på til at kunne varetage den type blended learning, som vores definition på side 4 repræsenterer. I tabel 2 nedenfor er faser og funktioner ifm. tilrettelæggelse, gennemførelse og evaluering af blended learning angivet i kolonne 1 . Den viden samt de færdigheder og kompetencer, der er nødvendige for varetagelse af funktionerne, er listet i kolonne 2, medens kolonne 3 beskriver, hvilke roller der skal udfyldes og hvem, der kan gøre dette, samt hvordan underviseren kan understøttes i de enkelte faser. Kolonne 3 er nærmere beskrevet og forklaret i afsnittet under tabellen. I kolonne 2 er viden, færdigheder og kompetencer placeret under niveau 1 og 2 . Under niveau 1 er listet den viden, de færdigheder og kompetencer, der er nødvendige for at skabe blended learning, der opfylder de krav, som vores definition opstiller. Under niveau 2 peges på, hvilken viden, færdigheder og kompetencer, der kræves for at videreudvikle blended learning formatet og arbejde med dette på et mere avanceret niveau, der muliggør en højere grad af fleksibilitet, studenterautonomi og deltagelse. Her har vi ladet os inspirere af Mirriahi et al. (2015) og Imbernón et al. (2011). Det basale niveau vil være velegnet ift. førsteårsstuderende og studerende, der ikke har være blended lærende før, mens det avancerede niveau kan bringes i spil ift. studerende på senere semestre og studerende med erfaring som blendede lærende. Niveau 1 og 2 peger også på en progression ift. kompetenceudvikling af undervisere. Hvad skal mestres indledningsvist, dvs. hvad er relevant på begynderniveau? Hvad skal mestres på sigt, dvs. hvad skal den avancerede blendede underviser vide og kunne? Funktioner, kompetencer og roller skal også ses i relation til den enkelte undervisers ansvar og de konkrete opgaver han/hun skal varetage. Nogle undervisere har alene ansvar for at gennemføre forløb, mens andre også har opgaver ift. tilrettelæggelse osv. 


\begin{tabular}{|c|c|c|}
\hline $\begin{array}{l}\text { 1. Fase og } \\
\text { funktioner }\end{array}$ & 2. Viden, fardigheder og kompetencer & $\begin{array}{l}\text { 3. Underviserroller, understøttelse og } \\
\text { unbundling }\end{array}$ \\
\hline $\begin{array}{l}\text { Før } \\
\text { Forberede } \\
\text { Planlægge } \\
\text { Designe } \\
\text { Klargøre platform og } \\
\text { værktøjer }\end{array}$ & $\begin{array}{l}\text { Niveau 1: } \\
\text { - Kunne identificere læringsmål og -niveauer og formulere motiverende } \\
\text { undervisnings- og læringsaktiviteter med afsæt i disse } \\
\text { - Kunne udvælge og formidle fagligt stof online og F2F } \\
\text { - Have kendskab til det virtuelle og F2F læringsrummets styrker og } \\
\text { - } \text { Kvagheder } \\
\text { - Hunne udarbejde læringsplaner - organisere undervisning } \\
\text { - } \text { Kunne designe et blend, hvor læringsrummene anvendes mest optimalt } \\
\text { - Kunne producere digitale undervisningsmaterialer } \\
\text { - Have kendskab til, kunne udvælge og anvende relevante digitale } \\
\text { værktøjer } \\
\text { - Kunne sætte kursusrummet op på en brugervenlig måde } \\
\text { - Kunne formulere en strategi for hensigtsmæssig online kommunikation } \\
\text { - Hed studerende samt retningslinjer for netiquette } \\
\text { Nave kendskab til og kunne anvende tekniske og pædagogiske } \\
\text { Niveau } 2 \\
\text { - } \quad \text { Have viden om og kunne designe fleksible forløb, der er tilpasset } \\
\text { studerendes behov, nærmeste udviklingszone og præferencer } \\
\text { - Have viden om og kunne designe forløb, der giver studerende } \\
\text { autonomi og valgmuligheder og øger deres deltagelse ift. eksempelvis } \\
\text { produktion af læringsressourcer }\end{array}$ & $\begin{array}{l}\text { Hvilke roller skal underviseren udfylde? } \\
\text { Planlægger/organisator } \\
\text { Fagekspert } \\
\text { Producent af digitale undervisningsmaterialer } \\
\text { Superbruger? } \\
\text { Hvilke ressourcepersoner kan inddrages } \\
\text { som støtte for underviseren? } \\
\text { Læringsdesigner/pædagogisk konsulent } \\
\text { E-læringskonsulent } \\
\text { IT-support } \\
\text { Multimediedesigner } \\
\text { Kolleger } \\
\text { Studentermedhjælpere } \\
\text { Modulsekretærer } \\
\text { Informationsspecialist } \\
\text { Copyright ekspert } \\
\text { Hvilke ressourcer kan stilles til } \\
\text { rådighed? } \\
\text { Workshops og kurser } \\
\text { Værktøjskasser med skabeloner }\end{array}$ \\
\hline $\begin{array}{l}\text { Under } \\
\text { Facilitere } \\
\text { Undervise } \\
\text { Interagere } \\
\text { Bedømme } \\
\text { Give og indsamle } \\
\text { feedback } \\
\text { Tilpasse } \\
\text { Samskabe }\end{array}$ & $\begin{array}{l}\text { Niveau } 1 \\
\text { - Kunne anvende digitale værktøjer } \\
\text { - Kunne facilitere online kommunikation og interaktion } \\
\text { - Kunne være tilstede online } \\
\text { - Kunne opbygge et F2F og virtuelt læringsrum, hvor de studerende er } \\
\text { trygge ved at bidrage } \\
\text { - Kunne træne de studerende i rollen som blended lærende } \\
\text { - Kunne skabe synergi og sammenhæng mellem online og F2F aktiviteter } \\
\text { - Kunne formidle fagligt stof F2F og virtuelt }\end{array}$ & $\begin{array}{l}\text { Hvilke roller skal underviseren udfylde? } \\
\text { Facilitator } \\
\text { Fagekspert } \\
\text { Underviser } \\
\text { Bedømmer } \\
\text { Superbruger? } \\
\text { Reflekteret praktiker } \\
\text { Hvilke ressourcepersoner kan inddrages } \\
\text { som støtte for underviseren? } \\
\text { E-læringskonsulent } \\
\text { IT-support }\end{array}$ \\
\hline
\end{tabular}




\begin{tabular}{|c|c|c|}
\hline & $\begin{array}{l}\text { - Kunne bedømme studerendes præstationer og produkter og give } \\
\text { konstruktiv feedback, feed forward og feed up til de studerende online } \\
\text { og F2F } \\
\text { - Kunne motiverer studerende til aktiv deltagelse både online og F2F } \\
\text { - Kunne stilladsere peer feedback } \\
\text { - Kunne indsamle og anvende data til justering og optimering af det } \\
\text { blendede forløb og de studerendes læring } \\
\text { Niveau 2: } \\
\text { - Kunne facilitere og stilladsere studerendes autonome læring og } \\
\text { deltagelse }\end{array}$ & $\begin{array}{l}\text { Kolleger } \\
\text { Studerende, studentermedhjælpere eller } \\
\text { undervisningsassistenter som facilitatorer } \\
\text { Studievejledere } \\
\text { Hvilke ressourcer kan stilles til } \\
\text { rådighed? } \\
\text { Workshops og kurser } \\
\text { Værktøjskasse } \\
\text { Blended studiestart for studerende }\end{array}$ \\
\hline $\begin{array}{l}\text { Efter } \\
\text { Evaluere } \\
\text { Reflektere }\end{array}$ & $\begin{array}{l}\text { Niveau 1: } \\
\text { - Kunne indsamle data om de studerendes læringsoplevelse, progression } \\
\text { og præstationer og analysere disse mhp. at identificere elementer, der } \\
\text { bør justeres } \\
\text { - Kunne reflektere over egen rolle og adfærd og effekten heraf samt lægge } \\
\text { en plan for rolle og adfærd i næste forløb } \\
\text { - Kunne analysere egen praksis og identificere behov for } \\
\text { kompetenceudvikling } \\
\text { - Have kendskab til og kunne søge sparring ift. tekniske og pædagogiske } \\
\text { problemstillinger } \\
\text { Niveau 2: } \\
\text { - Kunne samskabe blendede forløb med studerende }\end{array}$ & $\begin{array}{l}\text { Hvilke roller skal underviseren udfylde? } \\
\text { Evalueringsekspert } \\
\text { Reflekteret praktiker } \\
\text { Superbruger? } \\
\text { Hvilke ressourcepersoner kan inddrages } \\
\text { som støtte for underviseren? } \\
\text { E-læringskonsulent } \\
\text { IT-support } \\
\text { Pædagogisk konsulent } \\
\text { Kolleger } \\
\text { Hvilke ressourcer kan stilles til } \\
\text { rådighed? } \\
\text { Workshops og kurser } \\
\text { Portfolio - refleksionsspørgsmål }\end{array}$ \\
\hline
\end{tabular}

Tabel 1. Oversigt over den blendede undervisers roller og kompetencer samt forslag til unbundling (se forklaring nedenfor). 


\section{Hvordan understøttes den blendede underviser bedst muligt?}

Da rollegalleriet og kompetence-paletten, der skal mestres, er kompleks og omfangsrig, og da underviserens tid til at erhverve sig ny viden, færdigheder og kompetencer er knap, er det vigtigt at overveje, hvordan den blendede underviser kan understøttes. En af de løsninger, der nævnes, er "unbundling" af underviserrollen (Abdous, 2011; Bates, 2015; Macfarlane, 2011; McCowan, 2017).

\footnotetext{
"[U]nbundling is the differentiation of tasks and services that were once offered by a single provider or individual (i.e. bundled) and the subsequent distribution of these tasks and services among different providers and individuals."

(Gehrke \& Kezar, 2015, s. 96)
}

I forhold til underviserrollen skal unbundling først og fremmest ses i lyset af den øgede anvendelse af teknologi i undervisningen (Macfarlane, 2011) og behovet for at kunne trække på ekspertviden om platforme og værktøjer. Hertil kommer varetagelsen af de helt nye roller, som blended learning fører med sig. I kolonne 3 i tabel 2 peger vi på mulige ressourcepersoner, der kan overtage nogle af underviserens opgaver ifm. faserne tilrettelæggelse, gennemførelse og evaluering af blended learning. Abdous (2011) nævner muligheden for at etablere et team af ressourcepersoner, der kan håndtere praktiske elementer, såsom at sætte kurserne op på institutionens e-læringsplatform, uploade og organisere materialer, klargøre værktøjer osv. Underviseren indtager primært rollen som fagekspert og udarbejder læringsaktiviteter og opgavebeskrivelser ud fra skabeloner. På den måde sker der en unbundling af underviserens rolle med det formål at lette underviserens opgaver samtidig med, at kvaliteten sikres. Ifm. gennemførelse af forløbet kan studentermedhjælpere, undervisningsassistenter eller studerende inddrages som facilitatorer af online aktiviteter og $\mathrm{i}$ evalueringsfasen kan eksempelvis evalueringseksperter inddrages.

Baran et al. (2011) advarer dog mod at umyndiggøre underviseren og gør opmærksom på vigtigheden af, at underviseren er aktivt engageret i de forskellige faser. Flere taler da også for en teamtilgang, hvor underviseren kan trække på underviserkolleger samt lærings- og supportenheder, der kan bidrage med relevant viden, færdigheder og kompetencer i hver af de 3 faser og dermed kvalificere underviserens rolle som blended underviser (Abdous, 2011; Bates, 2015; Carril et al., 2013; Jia, 2017). Der kan desuden udvikles ressourcer til underviserne, såsom skabeloner, eksempler og retningslinjer, der stilladserer underviserens arbejde med at designe, gennemføre og evaluere effektiv blended learning. Hertil kommer kompetenceudviklingsforløb, der understøtter underviseren i at arbejde med og professionalisere sin nye rolle som blended underviser.

\section{Konklusion og perspektivering}

Denne artikel bidrager med viden om de roller og kompetencer, der er behov for ifm. tilrettelæggelse, gennemførelse og evaluering af effektiv blended learning og forslag til alternative måder at organisere disse opgaver på i praksis. På baggrund af litteraturstudier blev rollen som designer af læringsoplevelser, e-læringskonsulent og facilitator samt funktionen at være tilstede online identificeret som de mest centrale opmærksomhedspunkter og udfordringer for den blendede underviser. Disse repræsenterer de dele af den blendede undervisers roller og kompetencer, der ligger længst væk fra den traditionelle underviserrolle og er samtidig udtryk for behovet for at sætte de studerendes læring i centrum for at opnå effektiv blended learning. 
6 fremsøgte tekster præsenterer et rollegalleri og/eller en kompetence-palette for den blendede underviser men har hvert sit fokus og formål, hvorfor det ikke har været muligt at vise en samlet fremstilling. De 6 tilgange indbefatter underviserroller og kompetencer relateret til konstruktivistiskfunderet blended learning, roller og funktioner i relation til blendede engelskkurser, IKT-kompetencer, et blended learning framework i form af et vurderingsskema, et rollegalleri bestående af den kognitive, affektive og ledelsesmæssige rolle samt professionelle opgaver og kompetencer relateret til underviserens overordnede rolle som facilitator af studerendes signifikante læring. Vi kan derfor konkludere, at der ikke er konsensus i litteraturen om, hvilke roller og kompetencer, der skal i spil ifm. blended learning og hvilke begreber og betegnelser, der skal anvendes. Samtidig er det at skabe et godt blend et underbelyst felt, og de fleste tekster koncentrerer sig om de roller og kompetencer, det kræver at varetage online delen af blended learning.

I et forsøg på at tilbyde en systematisk fremstilling af den blendede undervisers roller og kompetencer, der kan anvendes i praksis, præsenterer vi vores bud i form af en oversigtstabel, hvor viden, færdigheder og kompetencer er listet i relation til den fase, de er tilknyttet i processen med at tilrettelægge, gennemføre og evaluere blended learning. Oversigten er omfattende, der er en stor grad af kompleksitet og alt i alt er det store, man kan måske ligefrem sige urimelige eller urealistiske krav, der stilles til underviseren. Skal denne f.eks. være superbruger af en lang række platforme og digitale værktøjer? Derfor anbefales, at man på sin uddannelsesinstitution diskuterer og træffer beslutning om, hvordan den blendede underviser bedst understøttes. Det bør overvejes, hvilke roller, underviseren skal varetage, om unbundling er mulig, dvs. om visse roller kan varetages af andre personer, om det er muligt at anvende en team-tilgang, hvor underviseren kan trække på forskellige ressourcepersoner i de forskellige faser og endelig hvilke ressourcer, herunder kompetenceudviklingstiltag, der bør stilles til rådighed for underviseren, så denne kan udfylde sine roller på kompetent vis.

Det er vores håb, at undervisere kan anvende oversigten til at vurdere egne kompetencer og identificere områder, hvor der er behov for udvikling. Samtidig er oversigten tænkt som inspiration for personer og enheder, der skal tilrettelægge kompetenceudvikling for undervisere, og endelig vil vi gøre ledere på alle niveauer opmærksomme på, at det er en kompleks opgave at varetage blended learning og opfordre til udvikling af institutionelle politikker, der kan medvirke til skabelsen af en blended learning kultur, sikre kvaliteten samt anerkende og belønne underviseres indsats.

I arbejdet med roller og kompetencer er det vigtigt ikke at skabe rigide standarder, der fastlåser underviseren ved at foreskrive bestemt adfærd (Baran et al., 2011). I stedet skal underviseren støttes i at finde sin nye identitet samt reflektere over og professionalisere rollen som blended underviser. Derfor er niveauer og progression tænkt ind i vores model over roller og kompetencer, sådan at underviseren gradvist kan udvikle sig og bevæge sig i retning af øget studenterautonomi og -deltagelse. 


\section{Bilag 1}

\section{Tabel 1}

\begin{tabular}{|c|c|c|}
\hline Rolle: instructional designer & Rolle: Facilitator 1 & Rolle: Facilitator 2 \\
\hline $\begin{array}{l}\text { Design kompetencer } \\
\text { Viden: Skal have forståelse for de } \\
\text { læringsniveauer, der knytter sig til } \\
\text { konstruktivistisk-baseret undervisning. } \\
\text { Kompetencer: } \\
\text { - Kunne definere mål for undervisningen. } \\
\text { - Kunne designe læreprocesser og } \\
\text { undervisningsformer der aktiverer de studerendes } \\
\text { indre motivation. } \\
\text { Funktioner: } \\
\text { - Underviseren laver og anvender ”learner } \\
\text { profiles” af hver studerende. } \\
\text { - Anvender læringsteknologi, der genkender de } \\
\text { studerendes læringsstil og tilpasser indhold, } \\
\text { præsentation og opgaver efter præferencer. } \\
\text { - Anvender data fra denne type læringsteknologi } \\
\text { som feedback på de studerendes oplevelse og } \\
\text { udbytte. } \\
\text { - Designer motiverende opgaver, der matcher den } \\
\text { enkelte studerendes kognitive udvikling og behov. } \\
\text { - Skaber ejerskab ved at inddrage de studerende, } \\
\text { f.eks. gennem forhandling af læringsmål. } \\
\text { - Designer, implementerer, anvender, fremmer og } \\
\text { moderer konstruktivistisk-baserede } \\
\text { undervisnings- og eksamensformer (både } \\
\text { individuelle og gruppe). } \\
\text { IKT-kompetencer: } \\
\text { - Indtænker IKT til aktivering af studerendes } \\
\text { indre motivation. }\end{array}$ & $\begin{array}{l}\text { - Kunne organisere studerendes } \\
\text { læringsmiljø. } \\
\text { Funktioner } \\
\text { - Underviseren udfordrer og giver den } \\
\text { enkelte studerende mulighed for } \\
\text { læring med udgangspunkt i dennes } \\
\text { behov og præferencer. } \\
\text { - Stiller rige undervisningsmaterialer, } \\
\text { der forstyrrer til rădighed. } \\
\text { - Skaber, vedligeholder og modererer } \\
\text { læringsfællesskaber, som udgør det } \\
\text { sociale miljø, der aktiverer studerendes } \\
\text { indre motivation. } \\
\text { - Udvikler og anvender } \\
\text { undervisningsmetoder og -teknikker } \\
\text { tilpasset præferencer og læringsstile, } \\
\text { der aktiverer studerendes indre } \\
\text { motivation. } \\
\text { IKT-kompetencer } \\
\text { Viden: Har viden om muligheder og } \\
\text { begrænsninger i relation til IKT } \\
\text { anvendt i blended learning. } \\
\text { Færdigheder: Kan anvende IKT på } \\
\text { avanceret niveau. }\end{array}$ & $\begin{array}{l}\text { - Kunne støtte og styrke studerendes motivation. } \\
\text { Funktioner: } \\
\text { - Underviseren støtter og styrker studerendes indre } \\
\text { motivation gennem monitoring af og feedback på læring. } \\
\text { - Fleksibel organisering og tilpasning af studerendes } \\
\text { betingelser for læring ud fra præferencer og behov. } \\
\text { - Tilpasser opgaver for bedre at matche studerendes } \\
\text { individuelle, kognitive udvikling. } \\
\text { - Støtter og styrker studerendes indre motivation via } \\
\text { læringsfællesskaber og anvendelse af relevante metoder. } \\
\text { Evalueringskompetencer } \\
\text { - Kunne designe og anvende evalueringsmetoder og - } \\
\text { teknikker, der støtter og styrker studerendes indre } \\
\text { motivation. } \\
\text { Funktioner og færdigheder: } \\
\text { - Anvender studerendes fejl som udgangspunkt for } \\
\text { rekonstruktion af læringsstrategier. } \\
\text { - Anvender forskellige former for formativ evaluering. } \\
\text { - Støtter og udvikler studerendes selv-monitorering og - } \\
\text { evaluering. } \\
\text { - Udvikler procedurer og værktøjer til generering af pålidelig } \\
\text { feedback på progressionen i de studerendes læring. } \\
\text { IKT-kompetencer: } \\
\text { - Har viden om muligheder og begrænsninger i relation til } \\
\text { IKT anvendt i blended learning. } \\
\text { - Har færdigheder til at anvende disse på avanceret niveau til } \\
\text { at støtte og styrke studerendes motivation. } \\
\text { - Indtænker anvendelse af IKT med det formål at støtte og } \\
\text { styrke studerendes indre motivation. }\end{array}$ \\
\hline
\end{tabular}

Tabel 1. Oversigt over Sajdak \& Koscielniaks (2014) roller, kompetencer, funktioner og færdigheder. Vores oversættelse. 


\section{Tabel 2}

\begin{tabular}{|c|c|c|c|}
\hline $\begin{array}{l}\text { Rolle: Designer af } \\
\text { undervisningens indhold }\end{array}$ & $\begin{array}{l}\text { Rolle: Organisator af } \\
\text { undervisningsaktiviteter }\end{array}$ & $\begin{array}{l}\text { Funktion: Integrere } \\
\text { undervis- } \\
\text { ningsmateriale/ressourc } \\
\text { er }\end{array}$ & $\begin{array}{l}\text { Funktion: Evaluere } \\
\text { undervisningsaktiviteter }\end{array}$ \\
\hline $\begin{array}{l}\text { - Skal have indgående } \\
\text { forstålse for målene for } \\
\text { undervisningen, } \\
\text { metoder, procedurer, de } \\
\text { studerendes } \\
\text { læringsforudsætninger } \\
\text { og -niveau m.m. } \\
\text { - Kunne designe } \\
\text { sammenhængende } \\
\text { online og offline opgaver } \\
\text { og aktiviteter, der tager } \\
\text { hensyn til de } \\
\text { studerendes } \\
\text { læringsforudsætninger- } \\
\text { og niveau. }\end{array}$ & $\begin{array}{l}\text { - Kunne designe en } \\
\text { positiv } \\
\text { læringsatmosfære. } \\
\text { - Kunne motivere de } \\
\text { studerende ved design af } \\
\text { varierende opgave- } \\
\text { baserede, individuelle og } \\
\text { kooperative } \\
\text { undervisningsaktiviteter } \\
\text { både offline og online. } \\
\text { - Kunne monitorere og } \\
\text { løbende tilpasse } \\
\text { undervisningsaktiviteter. }\end{array}$ & $\begin{array}{l}\text { - Har opdateret viden } \\
\text { om den teknologiske } \\
\text { udvikling ift. produktion } \\
\text { af online } \\
\text { undervisningsmateriale. } \\
\text { - Kunne udvælge og } \\
\text { (re)producere relevant } \\
\text { online } \\
\text { undervisningsmateriale. } \\
\text { - Løbende kunne udvikle } \\
\text { og tilpasse online } \\
\text { undervisningsmateriale/ } \\
\text { ressourcer ift. } \\
\text { læringsmål og de } \\
\text { studerendes lærings- } \\
\text { forudsætninger og - } \\
\text { niveau, samt den givne } \\
\text { undervisningskontekst. }\end{array}$ & $\begin{array}{l}\text { - Kunne evaluere de } \\
\text { studerendes } \\
\text { performance formativt } \\
\text { offline og online bl.a. } \\
\text { gennem indsamling af } \\
\text { data. } \\
\text { - Kunne supervisere og } \\
\text { motivere de studerende } \\
\text { til at færdiggøre opgaver. } \\
\text { - Kunne give feedback og } \\
\text { moderere diskussioner. }\end{array}$ \\
\hline
\end{tabular}

Tabel 2. Oversigt over Jias (2017) roller og funktioner. Vores oversættelse.

\section{Tabel 3}

\begin{tabular}{|c|c|c|}
\hline Forberedelse & $\begin{array}{l}\text { Undervisning (Teaching the } \\
\text { class) }\end{array}$ & $\begin{array}{l}\text { Evaluering af studerendes } \\
\text { viden }\end{array}$ \\
\hline $\begin{array}{l}\text { Funktioner/opgaver: } \\
\text { Lecture } \\
\text { - Træffe beslutning om, hvordan } \\
\text { og i hvilket læringsrum stoffet } \\
\text { skal formidles, og hvordan det } \\
\text { skal organiseres. } \\
\text { Classes } \\
\text { - Tilrettelægge individuelle } \\
\text { opgaver for studerende og } \\
\text { gennemgang af disse samt træffe } \\
\text { beslutning om, hvilket } \\
\text { læringsrum, det skal foregå i. } \\
\text { - Sætte tid af til at besvare } \\
\text { studerendes spørgsmål. } \\
\text { Laboratory classes } \\
\text { - Anbefaler at disse foregår F2F, } \\
\text { da det vil kræve avanceret } \\
\text { teknologi og intensiv forberedelse } \\
\text { at gennemføre disse online. } \\
\text { Team work and thesis } \\
\text { - Angives som værende virtuel } \\
\text { (remote) af natur med behov for } \\
\text { konsultation i bestemte faser. } \\
\text { Forberedelse: }\end{array}$ & $\begin{array}{l}\text { Vigtige IKT skills: } \\
\text { - Kommunikere med } \\
\text { kursusdeltagere. } \\
\text { - Tilpasse og ajourføre } \\
\text { eksisterende materiale ud fra den } \\
\text { aktuelle studentergruppes behov } \\
\text { og evt. udefrakommende } \\
\text { ændringer (ift. software, } \\
\text { hardware, litteratur etc.). } \\
\text { - Præsentere information til } \\
\text { relevante målgrupper på } \\
\text { platformen, sådan at disse let kan } \\
\text { tilgå denne. } \\
\text { - Organisere, monitorere, } \\
\text { kommunikere med og lede } \\
\text { projektgrupper med brug af } \\
\text { relevante værktøjer på } \\
\text { platformen. } \\
\text { - Lede virtuelle seminarer og } \\
\text { diskussioner. Afslutte board } \\
\text { discussions med et resumé. } \\
\text { Funktion } \\
\text { - Afholde lokale konsultationer og } \\
\text { gøre det muligt for studerende at } \\
\text { tilmelde sig via platformen. }\end{array}$ & $\begin{array}{l}\text { Funktion/opgaver: } \\
\text { - Forberede spørgsmål, organisere } \\
\text { processen og supervision, } \\
\text { evaluere, distribuere resultater og } \\
\text { sikre arkivering. } \\
\text { Kompetencer ifm. en } \\
\text { elektronisk } \\
\text { evalueringsmodel: } \\
\text { - Udvikle eksamensressourcer, } \\
\text { inklusive multimedier. } \\
\text { - Kunne udvælge hensigtsmæssige } \\
\text { metoder til test af viden og sætte } \\
\text { grænseværdi for bestået. } \\
\text { - Kunne vurdere spørgsmål og } \\
\text { progression i en test, eksamen } \\
\text { eller kursus. } \\
\text { - Kunne arbejde i henhold til } \\
\text { kvalitetsstandarder og den } \\
\text { aktuelle portals brugerinterface. } \\
\text { - Have IKT-kompetencer til at } \\
\text { undervise og organisere kurser på } \\
\text { distancen via en e- } \\
\text { læringsplatform. }\end{array}$ \\
\hline
\end{tabular}




\begin{tabular}{|l|l|l|}
\hline $\begin{array}{l}\text { - Udarbejde en detaljeret tidsplan } \\
\text { til studerende med angivelse af } \\
\text { elektroniske ressourcer, } \\
\text { obligatoriske og valgfrie }\end{array}$ & $\begin{array}{l}\text { - Anvende platformen ifm. } \\
\text { studerendes aflevering af endelige } \\
\text { aktiviteter og evalueringsform. }\end{array}$ & \\
- Anvende e-læringsplatformens & & \\
kalenderfunktion til at give & & \\
studerende overblik over, hvilket & & \\
materiale, der skal studeres & & \\
hvornår, tidsfrister for aflevering & & \\
af opgaver, vejledende & \\
tidsforbrug, sværhedsgrad, hvad & & \\
der kræves af studerende samt & & \\
relevante links. & \\
- Forberede læringsmaterialer. & & \\
\hline
\end{tabular}

Tabel 3. Oversigt over Roszak et al.s (2014) bud på, hvordan blended learning forberedes og gennemføres og hvordan studerendes læring evalueres. Vores oversættelse. 


\section{Tabel 4}

\begin{tabular}{|c|c|c|c|}
\hline Resources & Activities & Support & Evaluation (Assessment) \\
\hline $\begin{array}{l}\text { - Gøre digitale ressourcer } \\
\text { tilgængelige for studerende, og hvor } \\
\text { hensigtsmæssigt lade de studerende } \\
\text { udvikle egne ressourcer som en del } \\
\text { af læringen. } \\
\text { - Stille ressourcer til rådighed til } \\
\text { formativ evaluering. } \\
\text { - Give studerende mulighed for at } \\
\text { øve sig, vurdere eget } \\
\text { præstationsniveau og sætte egne } \\
\text { læringsmål. }\end{array}$ & $\begin{array}{l}\text { - Udvælge de aktiviteter, der skal } \\
\text { gennemføres online og F2F. } \\
\text { - Designe aktiviteter således at de } \\
\text { matcher læringsmålene og overveje, } \\
\text { hvordan teknologien kan anvendes } \\
\text { til at understøtte de studerendes } \\
\text { læring. } \\
\text { - Sikre integration mellem online og } \\
\text { F2F miljøerne, således at de } \\
\text { læringsaktiviteter, der finder sted i } \\
\text { de to læringsrum, støtter hinanden i } \\
\text { stedet for at overlappe og gentage. } \\
\text { - Identificere og adressere } \\
\text { studerendes særlige behov og } \\
\text { præferencer og anvende teknologi til } \\
\text { at imødekomme disse. } \\
\text { - Kunne vurdere teknologier og } \\
\text { udvælge den, der på mest } \\
\text { hensigtsmæssig vis vil understøtte } \\
\text { opnåelse af læringsmålene i en given } \\
\text { kontekst. Herunder have viden om } \\
\text { forskellige teknologiers affordances. }\end{array}$ & $\begin{array}{l}\text { - Kunne støtte studerendes } \\
\text { udvikling af digital literacy. } \\
\text { - Kunne håndtere studerendes } \\
\text { teknologiske erfaringer og } \\
\text { forventninger. } \\
\text { - Kunne træne de studerendes op til } \\
\text { rollen som blended lærende. } \\
\text { - Kunne identificere de studerendes } \\
\text { tekniske færdigheder og stille } \\
\text { træningsressourcer til rådighed om } \\
\text { effektiv anvendelse af værktøjerne. } \\
\text { - Kunne anvende en bred vifte af } \\
\text { interaktive værktøjer for at give de } \\
\text { studerende forskellige muligheder } \\
\text { for at interagere med hinanden, } \\
\text { akademikere og andre eksterne } \\
\text { eksperter. } \\
\text { - Sikre løbende feedback for at } \\
\text { understøtte studerendes læring. } \\
\text { - Anvende teknologi til at give } \\
\text { effektiv feedback i tide og i } \\
\text { forskellige formater. } \\
\text { - Anvende peer feedback ifm. blog-, } \\
\text { diskussionsfora-aktiviteter eller peer } \\
\text { review værktøjer. }\end{array}$ & $\begin{array}{l}\text { - Anvende teknologi til design af } \\
\text { autentiske og komplekse opgaver. } \\
\text { - Anvende teknologi til differentieret } \\
\text { evaluering, hvor studerende făr } \\
\text { mulighed for at vurdere, hvordan de } \\
\text { bedst kan demonstrere deres læring } \\
\text { og for at vælge mellem forskellige } \\
\text { afleveringsformater. } \\
\text { - Give de studerende mulighed for } \\
\text { løbende at følge egen progression og } \\
\text { præstationer. } \\
\text { - Bede de studerende sætte mål for } \\
\text { egen læring og gøre det muligt for } \\
\text { dem at følge op på, hvor langt de er } \\
\text { kommet ift. disse mål. } \\
\text { - Anvende selv og peer evaluering } \\
\text { med brug af rubrics. }\end{array}$ \\
\hline
\end{tabular}

Tabel 4. Sammenfatning af standarderne i Mirriahi et al.s blended learning framework. Vores oversættelse. 


\section{Tabel 5}

\begin{tabular}{|l|l|l|}
\hline Den kognitive rolle & Den affektive rolle & Den ledelsesmæssige rolle \\
\hline - gør brug af video og lyd til at & - understøtter læring gennem & - laver læringsplaner for de \\
understøtte de studerendes & leg. & studerende. \\
læring. & - opfordrer de studerende til at & - laver undervisningsskemaer. \\
- anbefaler online & - opfrykke deres følelser. & - kontrollere tempoet. \\
læringsressourcer. & - hjælper de studerudvekling. & - holder disciplin. \\
- Uddyber/forklarer fokus i & komme tættere på hinanden. & - sætter regler for og regulerer \\
læringsmateriale. & - hjælper de studerende med at & udførelsen af aktiviteter. \\
- hjælper de studerende på rette \\
vej ift. misforståelser. & holde fokus. & - fører protokol over de \\
- hjælper de studerende med at & - opfordrer til selvstændig & studerendes øvelser. \\
analysere læringsindhold. & undersøgelse af svar. & - tilpasser øvelser/aktiviteter til \\
- kommenterer og giver & - gør læringen mere interessant & de studerendes behov. \\
feedback på studenterarbejde. & og mindre stressfyldt for de & \\
-giver gode råd ift. & studerende. & \\
gennemførelse af øvelser og & - bringer forskellige ting op til & \\
viser studerende vejen ved & diskussion. & \\
læringsaktiviteter. & \multicolumn{2}{|l}{} \\
\hline
\end{tabular}

Tabel 5. Adfærd knyttet til underviseres kognitive, affektive og ledelsesmæssige rolle baseret på Huangs (2019) spørgeskemamodel til undersøgelser af underviserroller.

\section{Tabel 6}

\begin{tabular}{|l|l|l|l|}
\hline Professionelle opgaver eller & \multicolumn{3}{|c|}{ Kompetenceområder } \\
\cline { 2 - 4 } aspekter af de 3 kompetencer & $\begin{array}{l}\text { Viden om og } \\
\text { brug af IKT } \\
\text { værktøjer }\end{array}$ & $\begin{array}{l}\text { Viden om og } \\
\text { anvendelse af } \\
\text { planlægnings- og } \\
\text { design-teknikker } \\
\text { i relation til } \\
\text { virtuelle miljøer }\end{array}$ & $\begin{array}{l}\text { Viden om og } \\
\text { anvendelse af } \\
\text { undervisnings- } \\
\text { metoder til e- } \\
\text { læring og b- } \\
\text { læring }\end{array}$ \\
\hline $\begin{array}{l}\text { Forstå og anvende den platform og de IT- } \\
\text { programmer, der er nødvendige for at } \\
\text { undervise i ens fag }\end{array}$ & & \\
\hline $\begin{array}{l}\text { Forstå aspekter nødvendige for design, } \\
\text { vedligehold og vurdering af værktøjer på } \\
\text { den virtuelle campus }\end{array}$ & & \\
\hline $\begin{array}{l}\text { Mestre værktøjer til kommunikation med } \\
\text { studerende (synkrone og asynkrone) }\end{array}$ & & \\
\hline Sidehåndtering & & \\
\hline Sidehåndtering sammen med studerende & & \\
\hline $\begin{array}{l}\text { Fremme interaktiv læring, gruppearbejde } \\
\text { og teamarbejde }\end{array}$ & & & \\
\hline $\begin{array}{l}\text { Understøtte kollaboration mellem } \\
\text { studerende }\end{array}$ & & \\
\hline Booste social konstruktion af viden & & \\
\hline $\begin{array}{l}\text { Udvikle kritiske evner og læring gennem } \\
\text { medstuderende og undervisere }\end{array}$ & & & \\
\hline $\begin{array}{l}\text { Forstå og anvende databaser, multimedie- } \\
\text { præsentationer og animationer: poste } \\
\text { videoer, aktiviteter og eksamener }\end{array}$ & & & \\
\hline $\begin{array}{l}\text { Forstå de elementer og ressourcer som } \\
\text { bruges til at fremme og gennemføre } \\
\text { løbende evaluering og til at rette } \\
\text { aktiviteter }\end{array}$ & & & \\
\hline
\end{tabular}




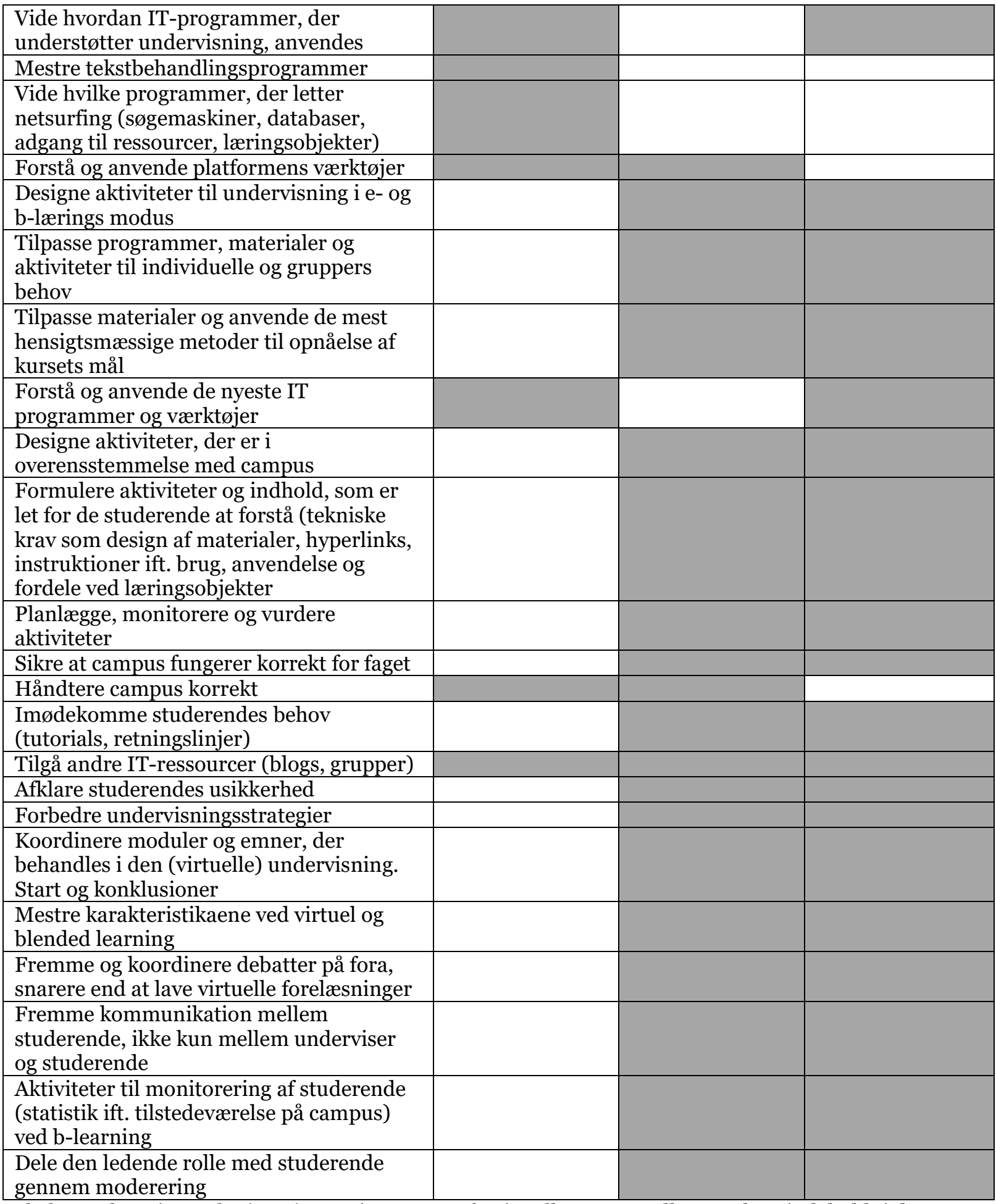

Tabel 6. Imbernón et al.s (2011) oversigt over professionelle opgaver eller aspekter indeholdt i de 3 identificerede kompetencer. Vores oversættelse. 


\section{Referencer}

Abdous, M. h. (2011). A process-oriented framework for acquiring online teaching competencies. Journal of Computing in Higher Education, 23(1), 60-77. doi:http://dx.doi.org/10.1007/s12528-010-9040-5

Al Ghamdi, A., Samarji, A. \& Watt, A. (2016). Essential considerations in distance education in KSA: Teacher immediacy in a virtual teaching and learning environment. International Journal of Information and Education Technology, 6(1), 17.

Anderson, T. (2017). How communities of inquiry drive teaching and learning in the digital age. North Contact, 116.

Anderson, T., Liam, R., Garrison, D. R. \& Archer, W. (2001). Assessing teaching presence in a computer conferencing context. Journal of Asynchronous Learning Networks, 5(2), 1-17.

Baran, E., Correia, A.-P. \& Thompson, A. (2011). Transforming online teaching practice: critical analysis of the literature on the roles and competencies of online teachers. Distance Education, 32(3), 421-439. doi:10.1080/01587919.2011.610293

Bates, T. (2015). Teaching in a digital age. Guidelines for designing teaching and learning for a digital age Hentet fra http://www.tonybates.ca/teaching-in-a-digital-age/

Bel, É. \& Mallet, M. (2006). Constructionist teaching in the digital age - A case study. Paper præsenteret.

Carril, P. C. M., Sanmamed, M. G. \& Sellés, N. H. (2013). Pedagogical roles and competencies of university teachers practicing in the e-learning environment. The International Review of Research in Open and Distributed Learning, 14(3), 462-487.

Charbonneau-Gowdy, P. \& Cechova, I. (2017). Blind Alleys: Capturing Learner Attention Online and Keeping it: The Challenges of Blended Learning Programs in Chile and the Czech Republic. Paper præsenteret på 12th International Conference on e-Learning (ICEL 2017).

Churchill, D., King, M., Webster, B. \& Fox, B. (2013). Integrating learning design, interactivity, and technology. Paper præsenteret på ASCILITE-Australian Society for Computers in Learning in Tertiary Education Annual Conference.

Coppola, N. W., Hiltz, S. R. \& Rotter, N. G. (2002). Becoming a virtual professor: Pedagogical roles and asynchronous learning networks. Journal of management information systems, 18(4), 169-189.

Donnelly, R. \& McAvinia, C. (2012). Academic development perspectives of blended learning Blended learning environments for adults: evaluations and frameworks (s. 1-18): IGI Global.

Dzuiban, C. D., Hartman, J. L. \& Moskal, P. D. (2004). Blended Learning. EDUCAUSE Centre for Applied Research. Research Bulletin, 7.

Forskningsministeriet, U.-o. (2013). Begreber. Kvalifikationsrammer. Hentet fra https://ufm.dk/uddannelse/anerkendelse-ogdokumentation/dokumentation/kvalifikationsrammer/begreber

Garrison, D. R. \& Kanuka, H. (2004). Blended learning: Uncovering its transformative potential in higher education. The Internet and Higher Education, 7(2), 95-105. doi:10.1016/j.iheduc.2004.02.001

Garrison, R. \& Vaughan, N. (2008). Blended learning in higher education: Framework, principles, and guidelines: John Wiley \& Sons.

Gehrke, S. \& Kezar, A. (2015). Unbundling the Faculty Role in Higher Education: Utilizing Historical, Theoretical, and Empirical Frameworks to Inform Future Research. I M. B. Paulsen (red.), Higher Education: Handbook of Theory and Research: Volume 30 (s. 93-150). Cham: Springer International Publishing.

Gerbic, P. (2011). Teaching using a blended approach - what does the literature tell us? Educational Media International, 48(3), 221-234. doi:10.1080/09523987.2011.615159

Gurley, L. E. (2018). Educators' Preparation to Teach, Perceived Teaching Presence, and Perceived Teaching Presence Behaviors in Blended and Online Learning Environments. Online Learning, 22(2), 197-220.

Huang, Q. (2019). Comparing teacher's roles of F2f learning and online learning in a blended English course. Computer Assisted Language Learning, 32(3), 190-209. doi:10.1080/09588221.2018.1540434

Imbernón, F., Silva, P. \& Guzmán, C. (2011). Teaching Skills in Virtual and Blended Learning Environments/Competencias en los procesos de ense-ñanza-aprendizaje virtual y semipresencial. Comunicar, 18(36), 107-114.

Jeffrey, L. M., Milne, J., Suddaby, G. \& Higgins, A. (2014). Blended learning: How teachers balance the blend of online and classroom components. Journal of Information Technology Education, 13.

Jia, H. (2017). Shift of English Teacher's Role In School-Based Blended Learning College English Course. DEStech Transactions on Social Science, Education and Human Science(eemt). 
Keller, C., Wass, S., Zetterlind, M., Ghassemali, E. \& Seifeddine, S. (2017). Teacher roles in a blended learning materials engineering master program:" It's not a new role, it's a new way!". Paper præsenteret på 26th EDEN Annual Conference 2017: Diversity matters, Jönköping, 13-16 June, 2017.

Kliger, D. P. \& Pfeiffer, E. P. O. T. R. L. B. C. P. (2011). Engaging Students in Blended Courses Through Increased Technology. Journal of Physical Therapy Education, 25(1), 11-14. doi:http://dx.doi.org/10.1097/00001416201110000-00003

Kurt, S. Ç. \& Yıldırım, İ. (2018). The Students' Perceptions on Blended Learning: A Q Method Analysis *. Kuram ve Uygulamada Egitim Bilimleri, 18(2), 427-446. doi:http://dx.doi.org/10.12738/estp.2018.2.0002

Macfarlane, B. (2011). The morphing of academic practice: Unbundling and the rise of the para-academic. Higher Education Quarterly, 65(1), 59-73.

Mathiasen, H. (2004). Lærer- og elevroller i projektorganiseret undervisning med IT. Tidsskrift for Universiteternes Efter- og Videreuddannelse (UNEV), 2(4). doi:10.7146/unev.v2i4.4963

McCowan, T. (2017). Higher education, unbundling, and the end of the university as we know it. Oxford Review of Education, 43(6), 733-748.

Mirriahi, N., Alonzo, D. \& Fox, B. (2015). A blended learning framework for curriculum design and professional development: Association for Learning Technology Journal. Research in Learning Technology, 23. doi:http://dx.doi.org/10.3402/rlt.v23.28451

Muhtia, A., Suparno, S. \& Sumardi, S. (2018). Blended Learning Using Schoology as an Online Learning Platform: Potentials and Challenges. Paper præsenteret på English Language and Literature International Conference (ELLiC) Proceedings.

Ocak, M. A. (2011). Why are Faculty Members Not Teaching Blended Courses? Insights from Faculty Members. Computers \& Education, 56(3), 689-699. doi:http://dx.doi.org/10.1016/j.compedu.2010.10.011

Okaz, A. A. (2015). Integrating Blended Learning in Higher Education. Procedia - Social and Behavioral Sciences, 186, 600-603. doi:10.1016/j.sbspro.2015.04.086

Roszak, M., Kołodziejczak, B., Kowalewski, W. \& Ren-Kurc, A. (2014). Academic blended learning-competences and tools. International Journal of Continuing Engineering Education and Life Long Learning, 24(3-4), 286301.

Sahni, J. (2019). Does Blended Learning Enhance Student Engagement? Evidence from Higher Education. Journal of e-Learning and Higher Education, 2019, 1-14. doi:10.5171/2019.121518

Sajdak, A. \& Koscielniak, M. (2014). Teacher competences and skills for enhancement of learners' motivation within constructivism-based blended learning. International Journal of Continuing Engineering Education and Life-Long Learning, 24(3/4), 219-236. doi:10.1504/IJCEELL.2014.063096

Salmon, G. (2011). E-Moderating: the key to teaching and learning online (3 udg.). New York: Routledge.

Salter, D. (2006). E-Scholars: Staff development through designing for learning. Paper præsenteret på 23rd Annual Conference of the Australasian Society for Computers in Learning in Tertiary Education: Who's Learning.

Shivam, R. \& Singh, S. (2015). Implementation of blended learning in classroom: a review paper. Int. J. Sci. Res. Publ, 5(11), 369-372.

Saalman, E. (2011). Engineering education teachers' pedagogical use of digital media shown in projects carried out in a Higher education course: Learning in Digital Media. Paper præsenteret på SEFI Annual Conference 2011.

Torrisi-Steele, G. \& Drew, S. (2013). The literature landscape of blended learning in higher education: The need for better understanding of academic blended practice. International Journal for Academic Development, 18(4), 371-383.

Ulriksen, L. (2014). God undervisning på de videregående uddannelser: en forskningsbaseret brugsbog. Frederiksberg: Frydenlund.

Vaughan, N. (2007). Perspectives on blended learning in higher education. International Journal on E-learning, 6(1), 81-94.

Whiteside, A. L. (2015). Introducing the social presence model to explore online and blended learning experiences. Online Learning, 19(2), n2.

Yu Lei, L. (2010). Research on college English teaching based on blended learning (s. 297-300): IEEE. 


\section{Inger-Marie F. Christensen}

Specialkonsulent

SDU Universitetspædagogik

Syddansk Universitet

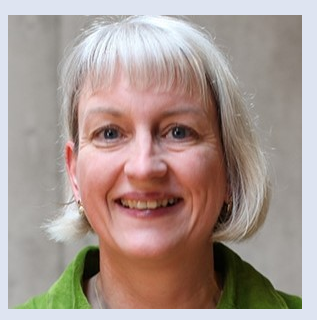

\section{Christopher Kjær}

E-læringskonsulent

SDU Universitetspædagogik

Syddansk Universitet

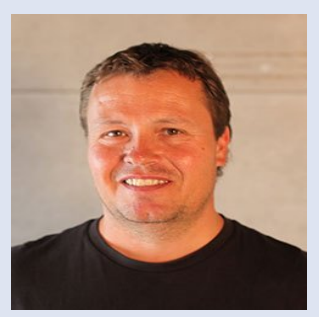

\section{Pernille Stenkil Hansen}

Specialkonsulent

SDU Universitetspædagogik

Syddansk Universitet

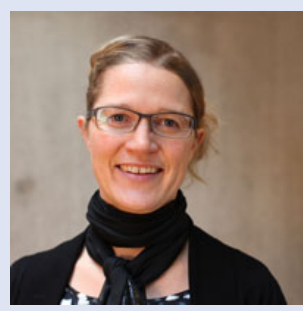

